\title{
Wolfe Mammography Classification
}

National Cancer Institute

\section{Source}

National Cancer Institute. Wolfe Mammography Classification. NCI Thesaurus. Code C38072.

A classification scheme according to Wolfe that assigns mammograms to four parenchymal patterns according to the distribution of fat and the prominence of the ducts. These patterns are dichotomized into low-risk (N1 and P1) and high-risk (P2, DY) patterns. The patterns are described as: breast consisting mostly of fatty tissue without visible ducts (N1), fatty breast with prominent ducts in the anterior portion occupying up to a quarter of the breast (P1), involuted breast with prominent ducts occupying more than a quarter of the breast (P2), dense breast tissue denoting dysplasia (DY). 